\title{
局所洗掘数值解析手法の 発電所放水口前面への適用性 APPLICATION OF COMPUTATIONAL METHOD FOR LOCAL SCOURING TO SAND BED IN FRONT OF POWER PLANTS
}

\author{
牛島 省 ${ }^{1} \cdot$ 清水 隆夫 ${ }^{2} \cdot$ 保坂 稔 ${ }^{3}$ \\ Satoru USHIJIMA, Takao SHIMIZU and Minoru HOSAKA \\ 1正会員 工博 (財)電力中央研究所 水理部（广270-11 我孫子市我孫子1646） \\ ${ }^{2}$ 正会員 工修 (財)電力中央研究所 水理部（广270-11 我孫子市我孫子1646） \\ 3正会員 東北電力株式会社 研究開発センター（广981 仙台市青葉区中山7-2-1）
}

\begin{abstract}
A refined computational method has been developed to predict local scour on a sand bed due to cooling-water jets discharged from power plants. The amount of sand particles detached from a sand bed is evaluated with a pick-up rate model proposed in the non-equilibrium conditions. The transportation of the picked up sands is calculated with an advection-diffusion equation with turbulent diffusivity and settling velocity. In order to increase the applicability to actual field, friction force caused by wave motions and various bottom boundary conditions are taken into account in the refined method.

The computational method is applied to an actual field in front of power stations, where sand bed profiles are surveyed. As a result of computation, while the predicted width of the scoured area is narrower than the measured results, it is shown that the vertical profiles on the center line, where the sand bed is most deeply scoured, are satisfactorily predicted with the present method.
\end{abstract}

Key Words: local scouring, warmed cooling-water discharge, numerical prediction, turbulence model, arbitrary Lagrangian-Eulerian, Boundary-fitted coordinate, surveyed sand-bed profile

\section{1.はじめに}

火力・原子力発電所から水中放流される温排水に より，放水口前面の海底砂面が局所的に洗掘される 事例が報告されている.このような局所洗掘が発生 すると, 海岸に面した各種の構造物の安定性に影響 が生ずる可能性もあるため, 事前に洗掘される砂面 形状を正確に把握するとともに，必要であれば洗掘 防止対策を施しておくことが重要となる。ささらに, これらの評価を経て設計された洗掘防止対策工の効 果を確認するためには，対策工を含む条件での局所 洗掘現象の予測が可能であることが望まれる.

温排水が水中放流される, ある発電所地点（以下 X地点）では, 放水口前面に局所洗掘現象の発生が 予測されたため, 建設時にコンクリートブロックの 敷設とSPAC工法（洗掘が予想される砂面を捨石と 目つぶし石で置換する工法 $\left.{ }^{1) .2)}\right)$ がなされた。この $\mathrm{X}$ 地点では, 放水口前面の海底地形のモニタリング 調查を発電所稼働前から継続的に実施しており, 放 流量の増加による局所洗掘の進行状況やSPAC工法 の有効性などが確認されている.
本研究では，著者らがこれまで開発を進めてきた 局所洗掘現象の数值解析手法 ${ }^{3), 4)}$ を用いて対策工が 施されたX地点の海底面形状の数值解析を行い, 実 測結果との比較を通じて適用性を検討する.

\section{2. 数值解析手法}

\section{(1)ALE法による砂面形状の取り扱い}

非定常的に変形する砂面形状を数值計算において 適切に考慮するため, 前報 ${ }^{3), 4)}$ と同様にALE法 ${ }^{5} に$ 基 づき，移動境界に適合する座標系を所定の時刻ごと に生成する手法をとった，利用した座標系は 3 次元 の境界適合座標系であり，物理空間と写像空間の座 標成分 $\left(x_{i}\right.$ および $\left.\xi_{m}\right)$ は, 次式のポアソン方程式 で関係づけられる6

$$
\frac{\partial^{2} \xi_{m}}{\partial x_{i}^{2}}=P_{m}
$$

ここで， $P_{m}$ は計算点間隔の粗密を制御する関数で ある。 


\section{(2)非等温乱流に対する基礎方程式}

発電所からの放流水は, 環境水よりも高い温度を 有するので, 流れ場を数值解析するために非等温場 の乱流モデルを利用した． 主な基礎方程式は以下の ように表される.

・運動方程式

$$
\begin{gathered}
\frac{D u_{i}}{D t}=-\frac{1}{\rho} \frac{\partial p}{\partial \xi_{m}} \frac{\partial \xi_{m}}{\partial x_{i}}-\left[1-\beta\left(T-T_{S}\right)\right] g_{i} \\
+\left(\varepsilon_{M}+v\right)\left(\frac{\partial^{2} u_{i}}{\partial \xi_{m} \partial \xi_{n}} \frac{\partial \xi_{m}}{\partial x_{j}} \frac{\partial \xi_{n}}{\partial x_{j}}+P_{m} \frac{\partial u_{i}}{\partial \xi_{m}}\right) \\
+\frac{\partial \varepsilon_{M}}{\partial \xi_{m}} \frac{\partial \xi_{m}}{\partial x_{j}}\left(\frac{\partial u_{i}}{\partial \xi_{n}} \frac{\partial \xi_{n}}{\partial x_{j}}+\frac{\partial u_{j}}{\partial \xi_{n}} \frac{\partial \xi_{n}}{\partial x_{i}}\right)-\frac{3}{2} \frac{\partial k}{\partial \xi_{m}} \frac{\partial \xi_{m}}{\partial x_{i}}
\end{gathered}
$$

- 温度 $T$ の方程式

$$
\begin{aligned}
\frac{D T}{D t}=\left(\varepsilon_{H}+\right. & \alpha)\left(\frac{\partial^{2} T}{\partial \xi_{m} \partial \xi_{n}} \frac{\partial \xi_{m}}{\partial x_{j}} \frac{\partial \xi_{n}}{\partial x_{j}}+P_{m} \frac{\partial T}{\partial \xi_{m}}\right) \\
& +\frac{\partial \varepsilon_{H}}{\partial \xi_{m}} \frac{\partial \xi_{m}}{\partial x_{j}} \frac{\partial T}{\partial \xi_{n}} \frac{\partial \xi_{n}}{\partial x_{j}}
\end{aligned}
$$

・乱れの運動エネルギー $k$ の方程式

$$
\begin{gathered}
\frac{D k}{D t}=\varepsilon_{M}\left(\frac{\partial u_{i}}{\partial \xi_{n}} \frac{\partial \xi_{n}}{\partial x_{j}}+\frac{\partial u_{j}}{\partial \xi_{n}} \frac{\partial \xi_{n}}{\partial x_{i}}\right) \frac{\partial u_{i}}{\partial \xi_{m}} \frac{\partial \xi_{m}}{\partial x_{j}} \\
-\beta g \varepsilon_{H} \frac{\partial T}{\partial \xi_{m}} \frac{\partial \xi_{m}}{\partial x_{3}} \\
+\left(\frac{C_{k}}{C_{v}} \varepsilon_{M}+v\right)\left(\frac{\partial^{2} k}{\partial \xi_{m}} \frac{\partial \xi_{m}}{\partial x_{j}} \frac{\partial \xi_{n}}{\partial x_{j}}+P_{m} \frac{\partial k}{\partial \xi_{m}}\right) \\
+\frac{C_{k}}{C_{v}} \frac{\partial \varepsilon_{M}}{\partial \xi_{m}} \frac{\partial \xi_{m}}{\partial x_{j}} \frac{\partial k}{\partial \xi_{n}} \frac{\partial \xi_{n}}{\partial x_{j}}-\varepsilon
\end{gathered}
$$

・乱れの運動エネルギーの散逸率 $\varepsilon$ の方程式

$$
\begin{gathered}
\frac{D \varepsilon}{D t}=C_{\varepsilon 1} \frac{\varepsilon}{k} \varepsilon_{M}\left(\frac{\partial u_{i}}{\partial \xi_{n}} \frac{\partial \xi_{n}}{\partial x_{j}}+\frac{\partial u_{j}}{\partial \xi_{n}} \frac{\partial \xi_{n}}{\partial x_{i}}\right) \frac{\partial u_{i}}{\partial \xi_{m}} \frac{\partial \xi_{m}}{\partial x_{j}} \\
+\left(\frac{C_{\varepsilon}}{C_{v}} \varepsilon_{M}+v\right)\left(\frac{\partial^{2} \varepsilon}{\partial \xi_{m}} \frac{\partial \xi_{m}}{\partial \xi_{n}} \frac{\partial \xi_{n}}{\partial x_{j}}+P_{m} \frac{\partial \varepsilon}{\partial \xi_{m}}\right) \\
+\frac{C_{\varepsilon}}{C_{v}} \frac{\partial \varepsilon_{M}}{\partial \xi_{m}} \frac{\partial \xi_{m}}{\partial x_{j}} \frac{\partial \varepsilon}{\partial \xi_{n}} \frac{\partial \xi_{n}}{\partial x_{j}}-C_{\varepsilon 2} \frac{\varepsilon^{2}}{k}
\end{gathered}
$$

上記の方程式中で, $u_{i}$ は $x_{i}$ 方向の平均流速成分, $\varepsilon_{M}$ と $\varepsilon_{H}$ は, それぞれ渦動粘性係数と乱流熱拡散係 数であり, 両者は $k$ と $\varepsilon$, 乱流プラントル数 $P_{r t}$ を用 いて表現される. 乱流プラントル数は, 成層度の影 響を受けるので, その効果を考慮したモデルを利用 した ${ }^{7)}$. 他の記号は, $\rho, p, g_{i}, \beta, T_{s}, v, \alpha$ がそれ ぞれ流体の密度, 圧力, 重力加速度, 熱膨張係数, 基淮温度, 動粘性係数, 熱拡散倸数である. なお,
乱流モデルの倸数值は, 標準的な值である， $C_{k}=C_{v}=0.09, C_{\varepsilon}=0.075, C_{\varepsilon 1}=1.44, C_{\varepsilon 2}=1.90$ を用いた。

砂面変形に伴い計算点の移動が生ずるが，この効 果を考慮して, 基碟方程式の左辺のLagrange微分オ ペレータは, 以下のように表される。

$$
\frac{D}{D t}=\frac{\partial}{\partial \tau}+\left(u_{i} \frac{\partial \xi_{m}}{\partial x_{i}}-\frac{\partial x_{i}}{\partial \tau} \frac{\partial \xi_{m}}{\partial x_{i}}\right) \frac{\partial}{\partial \xi_{m}}
$$

ここで $t$ とは，それぞれ物理空間と写像空間にお ける時間であるが，両者は等しいものとしている. 上記の各基礎方程式は, Lagrangeスキーム上で離散 化される ${ }^{8)}$. 移流項の計算には, 3 次元局所スプラ イン内挿法 ${ }^{8)}$ を利用し, 3 次精度で解析がなされる ものとした.

また, 計算速度を向上させるため, 写像空間中に おける圧力の行列解法には, 前処理付きの双共役勾 配安定法 (PCG法) を利用するものとした ${ }^{9}$.

\section{(3) 移動砂量の計算方法}

前報3),4) では，砂粒子の移動形態として，掃流移 動と浮遊移動という区分を設け，それぞれに対して 提案されたモデルを利用して評価を行い，全体の移 動砂量を求めた。一方, Olsen and Melaaen ${ }^{10)}$ は, 構 造物回りの砂面の局所洗掘現象を数值解析する際に, 砂の移動形態が全て浮遊移動であるとしたモデリン グを行い，実験結果との良好な一致を見ている. Olsenらの砂移動のモデリングに関しては, 適用性 に関する詳細な検討が必要であると考えられるが, 数值解析上は掃流移動と浮遊移動を別個に評価する 手法よりも扱いが極めて容易であるため, 本研究で もOlsenらと同様の手法を用いることとした.

本研究では, 底面での砂粒子濃度は, 非平衡状態 の移動砂に対して提案されたpick-up rate ${ }^{11)}\left(p_{S}\right)$ か ら計算されるものとした。 $p_{S}$ を用いれば, 単位時 閒内に単位面積の砂面から離脱する砂粒子の質量 $d W$ は以下の関倸から求められる.

$$
\begin{gathered}
d W=p_{S}\left(\frac{A_{3}}{A_{2}} d\right) \sigma \\
=0.03 \tau_{*}\left(1-0.035 / \tau_{*}\right)\left[\frac{d}{(\sigma / \rho-1) g}\right]^{-0.5}\left(\frac{A_{3}}{A_{2}} d\right) \sigma
\end{gathered}
$$

ここに, $A_{2}$ と $A_{3}$ は形状係数 ${ }^{11)}, d$ と $\sigma$ は砂粒子の 粒径と密度， $\tau_{*}$ は無次元掃流力である.この $d W$ を 用いて, 底面に接する計算セル内の砂粒子の濃度分 
布を求める. 底面から離脱した流体中の砂粒子の濃 度 $C$ は，次式の移流拡散方程式により評価される。

$$
\begin{gathered}
\frac{\partial C}{\partial \tau}+\left(U_{m}^{*}-U_{0 m}\right) \frac{\partial C}{\partial \xi_{\mathrm{m}}} \\
=\left(\lambda+\varepsilon_{S}\right)\left(\frac{\partial^{2} C}{\partial \xi_{m}} \frac{\partial \xi_{n}}{\partial x_{\mathrm{j}}} \frac{\partial \xi_{\mathrm{n}}}{\partial x_{\mathrm{j}}}+P_{m} \frac{\partial C}{\partial \xi_{\mathrm{m}}}\right) \\
+\frac{\partial \varepsilon_{S}}{\partial \xi_{m}} \frac{\partial \xi_{m}}{\partial x_{\mathrm{j}}} \frac{\partial C}{\partial \xi_{n}} \frac{\partial \xi_{\mathrm{n}}}{\partial x_{\mathrm{j}}}
\end{gathered}
$$

ここで， $\lambda$ と $\varepsilon_{s}$ は砂粒子の濃度に対する分子拡散係 数および乱流拡散係数である。また， $U_{m}^{*}$ と $U_{0 m}$ は それぞれ砂粒子濃度の移流速度と移動境界に追随す るための計算点の移動速度の反変成分であり，特に $U_{m}^{*}$ は沈降速度 $w_{0}$ を考慮して次式で与えられる。

$$
U_{m}^{*}=\left(u_{j}-w_{0} \delta_{3 j}\right) \frac{\partial \xi_{\mathrm{m}}}{\partial x_{\mathrm{j}}}
$$

$\delta_{3 j}$ はクロネッカーのデルタであり, 鉛直方向 $\left(x_{3}\right.$ 方向）に対してのみ，沈降速度が考慮されることを 示している.

なお，発電所前面においては，放流水と波浪によ り生ずる底面せん断力が海底砂面に作用すると考え られる．波と流れが共存する場における底面せん断 力の評価は容易でないため, ここでは砂面に作用す るせん断力 $\tau_{b}$ が, 放流水によるせん断力 $\tau_{f}$ と波に よるせん断力 $\tau_{w m}$ の和であると考えた． $\tau_{f}$ は粗面対 数則から計算され， $\tau_{w m}$ はJonsson ${ }^{12)}$ の評価式を利用 して, 現地観測された有義波から求めるものとした.

\section{（4）砂面形状の計算方法}

(8)式の移流拡散方程式を解析することにより， 流体中の砂粒子の濃度分布が求められる.この砂粒 子濃度に各位置での流速成分を乗じて鉛直方向に積 分することにより，その方向へ輸送される移動砂量 が計算される. 水平方向 $x_{\mathrm{i}}(i=1,2)$ の移動砂量を $q_{S i}$ とすれば, 砂面高さ $B$ は次式から求められる.

$$
(1-\gamma) \frac{\partial B}{\partial t}+\frac{\partial q_{S i}}{\partial x_{i}}=0
$$

ここに $\gamma$ は砂の空隙率である.この砂の連続式も他 の基礎方程式と同様に写像空間上で解析される.

(5) 洗掘防止対策工のモテル

水中放流を行う放水口前面には，一般にコンクリー トブロックなどの洗掘防止対策工が施される．洗掘
防止対策工がなされた状態での海底砂面の洗掘状況 を予測するためには, 砂面や固定床面などが共存す る条件下で計算を進めることが必要となる。

洗掘防止対策のための有効な工法として, SPAC 工法が提案されている(1),2)。このSPACが施された 領域は完全な固定床面ではなく, 沖側の砂面が洗掘 されることにより，上流側の搭石が自然に洗掘斜面 を覆うように展開していく．計算ではSPACの低下 は, 沖側の底面低下量がSPACの安息角を越えた場 合にのみ生ずるものとした．また，コンクリートブ ロックが敷かれた領域は, 砂の堆積は生じうるが, 初期位置からの低下がない固定床面として扱うもの とした。

\section{3. 現地実測結果との比較}

\section{(1) 発電所現地での実測の概要}

温排水が水中放流されるX地点において, 発電所 稼働前から継続的に海底面形状のモニタリングが行 われている。モニタリング調査は1992年から1997年 まで各年 1 回ずつ実施されており，1995年以前の調 查では精密音響測深機を用い, 1996年以降の実測で はより高精度の計測を行うため, マルチビーム測深 ソナーを利用した。

X地点における放水口前面の初期の底面条件は, 図一 1 に示すとおりである. 放水口前面にはコンク リートブロックが設置されており，途中で高低差約 $1.3 \mathrm{~m}$ の下り勾配がある. コンクリートブロック周辺 にはSPACが配置され，その周辺部が海底砂面に接 続している．放水口は中心間隔 $5 \mathrm{~m}$ で 3 管あり，各 管の放流平均流速は約 $5 \mathrm{~m} / \mathrm{s}$ である.

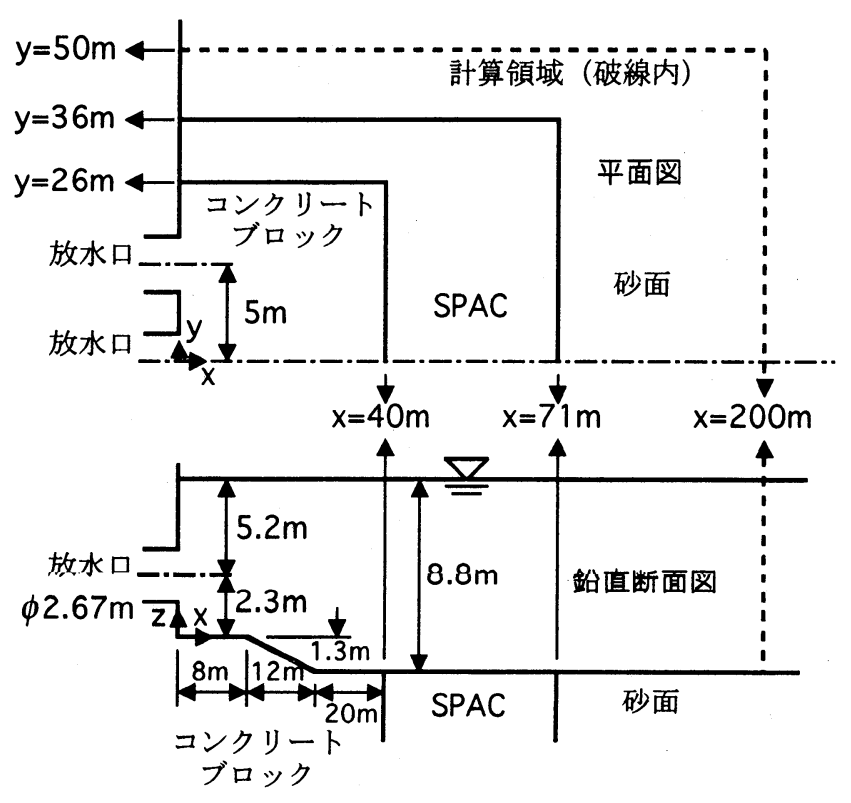

図-1 放水口前面の底面条件 
$\mathrm{X}$ 地点では発電所建設の進行に伴い，まず 1 管の 放水口のみからの水中放流が約 1 年半続けられた. その後，2 管からの放流が1997年7月の時点で約 2 年半続けられた。なお,これまでの実測期間中では 3 管での放流は行われていない，本報で計算結果と の比較に用いる実測值は，1管放流開始から約 1 年 半後の1994年の実測結果, また 2 管放流開始から約 1 年半および約 2 年半経過した時点の1996年および 1997年の実測結果である.

\section{(2)現地局所洗掘現象の計算条件}

X地点現地を対象とした数值解析では, 図ー1に 示したように，流下方向 $200 \mathrm{~m}$, 護岸方向に $50 \mathrm{~m}$ まで の中心軸に対称な片側の領域を計算対象とした．水 深は, LWL時の值を用いて, 放水口前面で $7.5 \mathrm{~m}$ と した. 解析対象領域中で設定された解析格子点数は, $\xi_{1} \times \xi_{2} \times \xi_{3}=51 \times 35 \times 15=26,775$ である.

自由液面はまさつが作用しない固定面として扱い, 下流端断面および側面は自由流出入境界とした。 中 心軸を含む対称面では対称条件を適用した，底面お よび放水口部分を除く上流端断面では粗面対数則か ら定められるまさつ力が作用するものとした.

現地の海底砂は, 実測結果に基づき, 粒径 $0.2 \mathrm{~mm}$ の均一な砂であるとした。波浪条件は，X地点で実 測された有義波のデータに基づき，波高 $0.7 \mathrm{~m}$, 波長 $35 \mathrm{~m}$ ，周期 5 秒とした。温度条件は，放流水を $27^{\circ} \mathrm{C}$, 環境水を $20^{\circ} \mathrm{C}$ とし, 温度差を $7^{\circ} \mathrm{C}$ とした。

\section{（3）実測結果と計算結果の比較}

計算は, 上述したX地点での放流条件の時間的な 変化を考慮して，まず 1 管放流時の砂面形状を計算 した. 次に， 1 管放流の条件で得られた砂面形状を 初期值として，2 管放流時の局所珗掘計算を開始し, 定常な砂面形状を求めた.

1 管放流時の局所洗掘計算を行った結果, 約 350 日が経過した時点で最大洗掘深が一定の值, $3.04 \mathrm{~m}$ となった. 砂面形状が定常となった時の鉛直断面内 の流速べクトルと等温線の分布を図一2に示した. 計算ではSPACの沖側の砂面が最も深く洗掘されて おり，SPAC先端部もわずかに低下している.

2 管放流時の局所洗掘計算では，計算開始から約 400日後に最大洗掘深が $4.56 \mathrm{~m}$ なる一定值となった. 最終的に得られた流速ベクトルと等温線の分布を図 ーろに示した.この結果に示されるように，放流条 件を 1 管放流から 2 管放流とした場合には, SPAC 前面の局所洗掘がさらに進行した。

図ー4および図ー5は, 砂面の実測結果と解析結 果を等高線表示で比較したものである.これらの図 において, 実測結果と計算結果を比較すると, 数値 計算により得られた洗掘領域の幅は，1 管放流およ び2管放流のどちらにおいても，実測結果より狭く 予測されている. この原因としては，冬季や荒天時 の高波浪により周辺の砂面が大きく変形したか, あ るいは波浪や恒流成分の影響などで放流水の流軸が y方向に変動していることが考えられる.

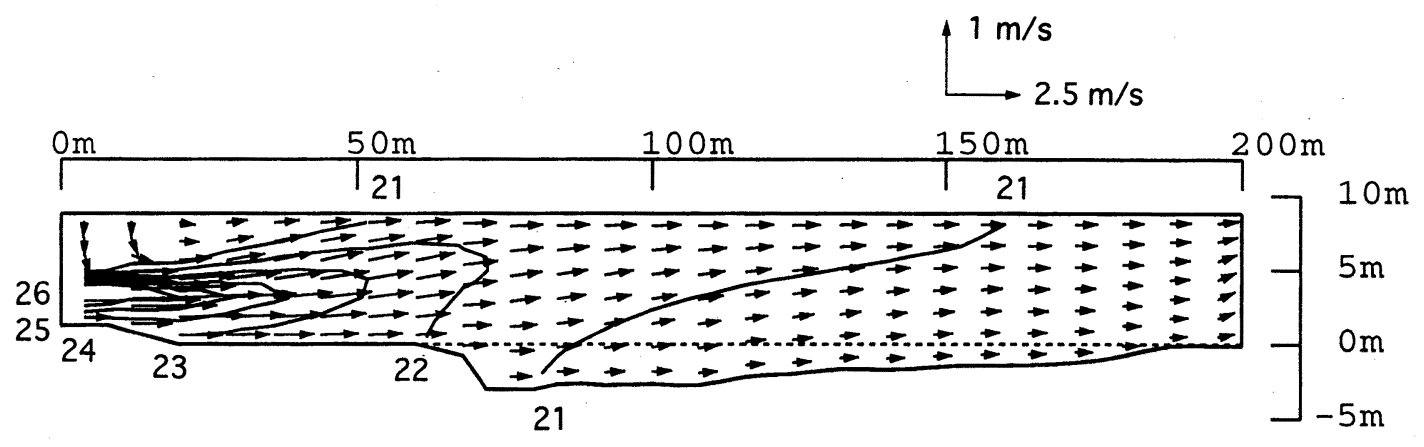

図一－1管放流時の定常な砂面上における流速ベクトルと等温線の計算結果（中心軸を含む対称面）

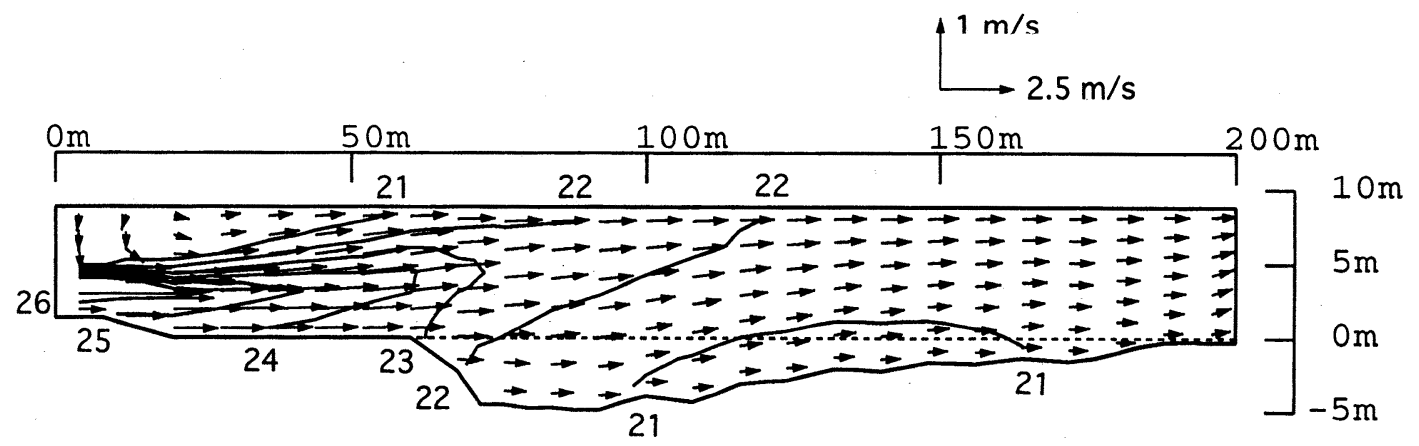

図一 32 管放流時の定常な砂面上における流速べクトルと等温線の計算結果（中心軸を含む対称面） 


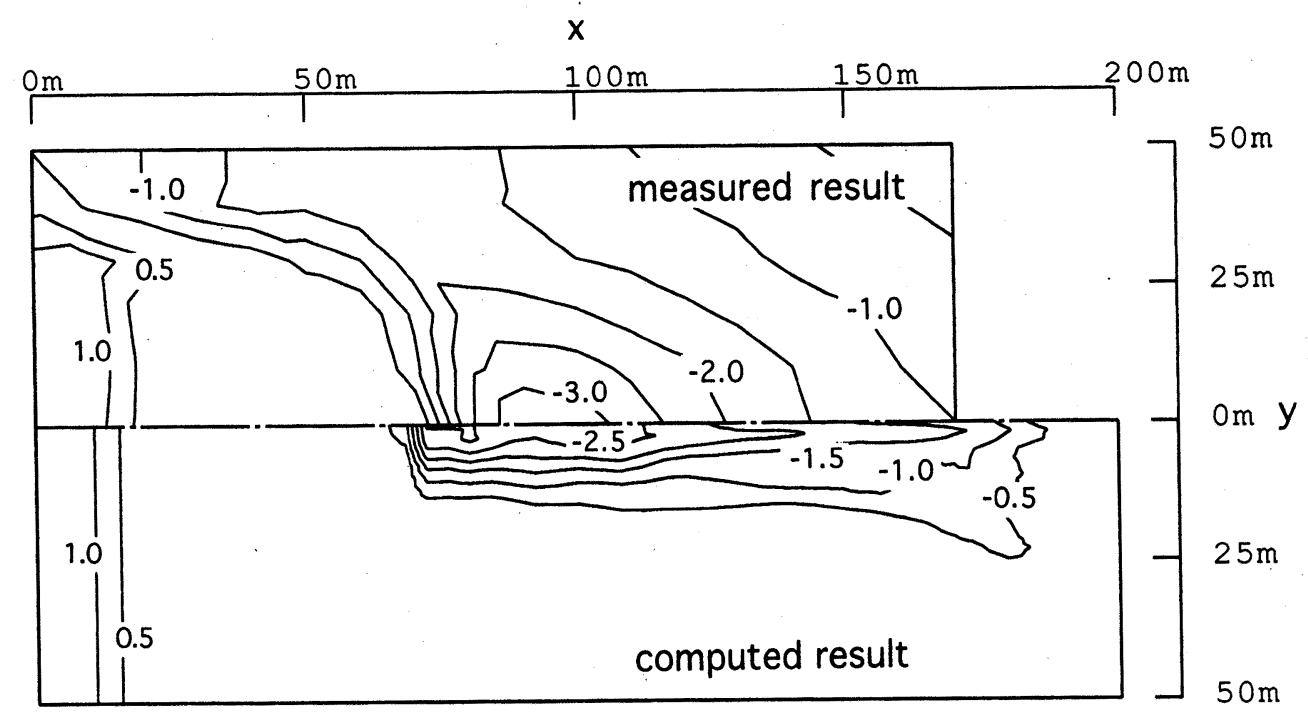

図-4 1 管放流時の砂面形状の比較（実測値は1994年）

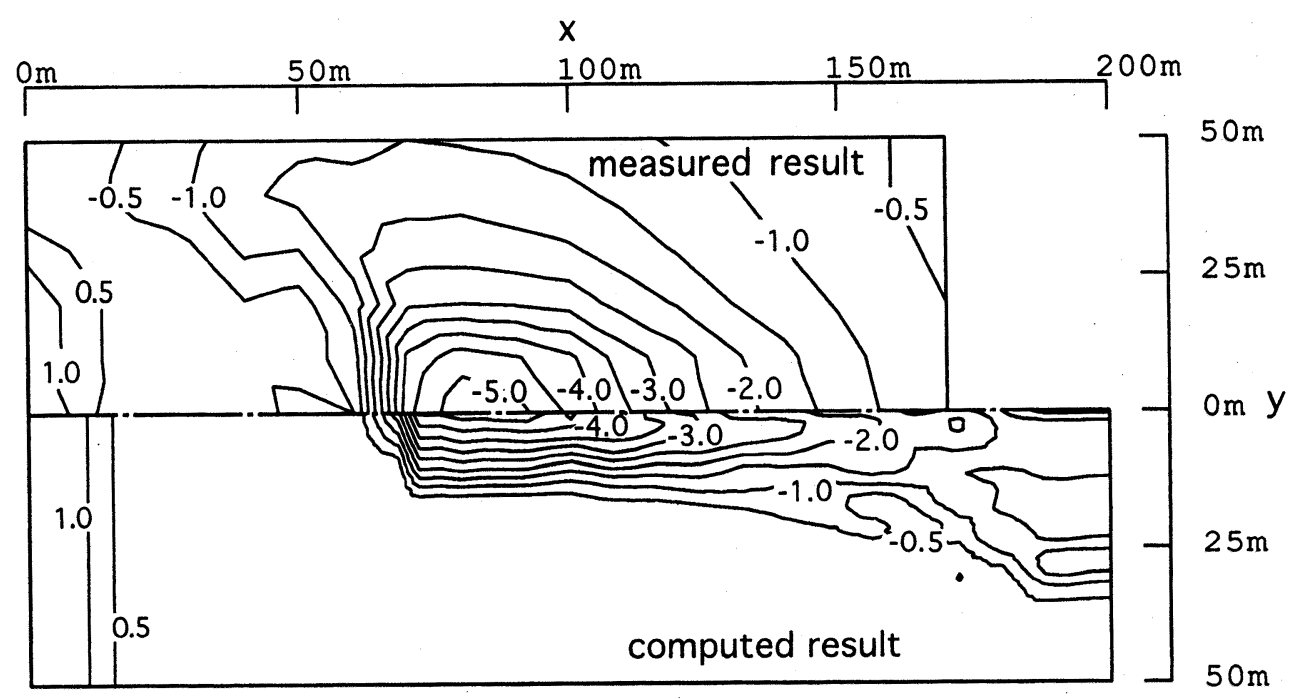

図-5 2 管放流時の砂面形状の比較（実測值は1997年）

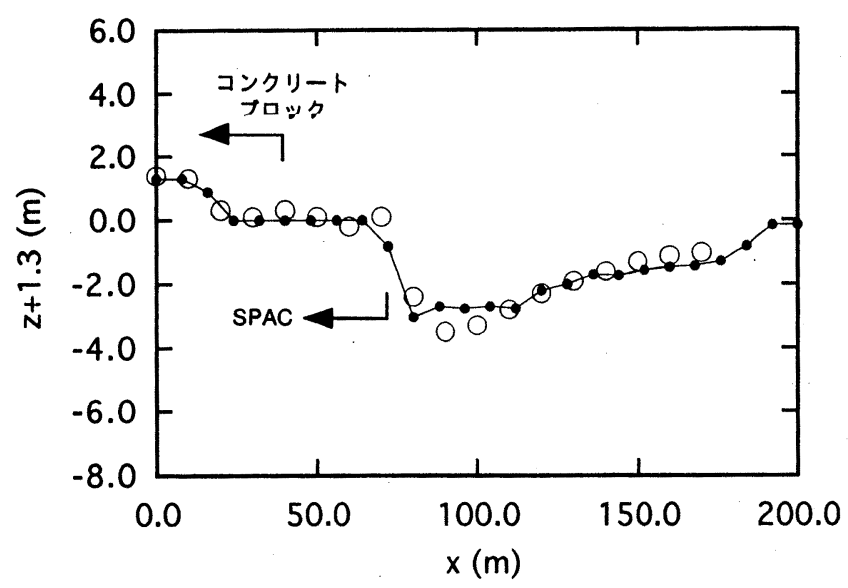

図-6 1 管放流時の中心断面内の砂面 形状の比較（Oは1994年の実測值、

○は計算結果)

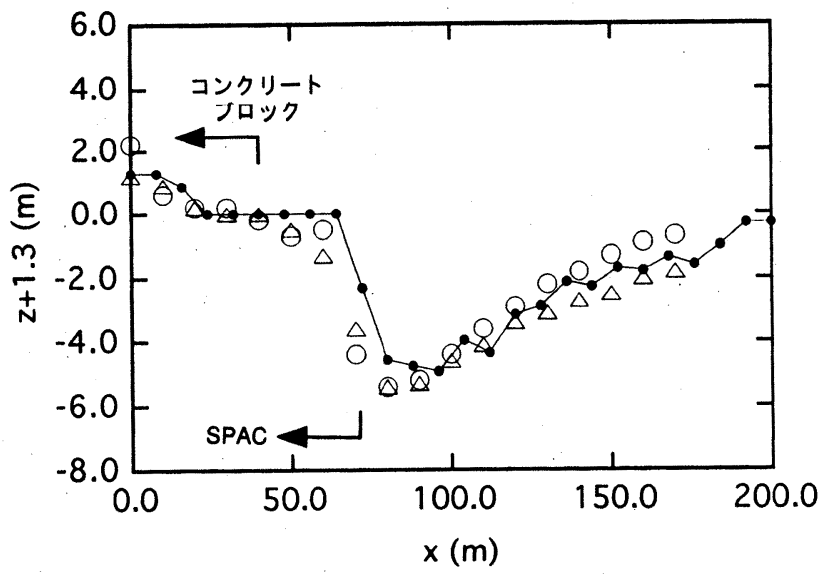

図-7 2 管放流時の中心断面内の砂面 形状の比較 $(\triangle は 1996$ 年の実測值, ○は1997年の実測值、○は計算結果) 
1 管放流および 2 管放流時の計算で得られた砂面 形状は，y方向には中心軸，また $\mathrm{x}$ 方向にはSPAC下 流部分で洗掘梁が大きくなったが，X地点現地の砂 面実測結果でも同様の傾向が見られた.このため, 中心軸を含む鉛直断面で両者の結果を比較したのが, 図一6，7である．これらの図では，初期の砂面高 さが 0 となるように, 縦軸を $z+1.3(\mathrm{~m})$ としている. 図一6は 1 管放流時の砂面形状を比較したもので, 両者はほぼ一致している。.また，図一 7 は 2 管放流 時の結果を比較したものであり，砂面形状はよく一 致しているが，SPACが低下している領域で，若干 の相違が見られる. 数值解析でSPACの低下が小さ くなったのは, 流下方向の解析メッシュ間隔が $4.0 \mathrm{~m}$ とやや粗かったことが 1 つ原因であると考えられ る.なお，図ー7中には，1996年と1997年の砂面実 測形状を合わせて示している。これらは，2管放流 開始からそれぞれ約 1 年半および 2 年半経過した時 点の実測結果であるが, 両者の相違は十分小さいこ とから, 荒天時の波浪等により多少の変動が生ずる 可能性はあるものの, すでに放流開始から約 1 年半 後の実測時点で放流水による洗掘砂面形状はほぼ定 常状態に達していたと考えられる.

以上のように，数值解析により洗掘領域の幅は実 測結果よりも狭く予測されたが，最大洗掘深が発生 する中心軸上においては実測結果とほぼ一致する砂 面形状が予測可能であることが示された. 今後は洗 掘領域幅の相違をもたらした原因を解明するととも に，その効果を解析手法に取り入れるなどの検討が 必要であるが，洗掘防止対策工であるSPACの設計 においては，当面は恒流成分の実測結果等に基づき， 沿岸方向に余裕幅を持たせることで対応可能である と考えられる.

なお，実測が行われたX地点においては，まだ展 開を開始していないSPACの捨て石部分にかなりの 余裕があり, 局所洗掘の放水口構造物への影響は生 じていない.

\section{4. おわりに}

本研究では，発電所現地で実際に生ずる局所洗掘 現象を精度よく評価するため, 移動砂量の評価方法 の改良を行い，波浪の影響や洗据防止対策工などの 底面境界条件を考慮できるものとした。

この計算手法を発電所現地へ適用した結果, 数值 解析による洗掘領域の幅は実測結果よりも狭いもの となったが，洗掘が最も進行した中心軸を含んだ鉛 直断面内の砂面形状は， 1 管および 2 管放流時の両 方の条件下において，実測結果とほぼ一致すること
が示された。

今後は洗掘領域幅の相違をもたらした原因の解明 や波と流れが共存する場での流体解析手法の開発な どを進めたいと考える.

\section{参考文献}

1）清水隆夫, 池野正明, 氏家久芳, 山内一晃: 波 と水中放流による洗掘対策工放の提案（その1）

-SPAC (Spreading Armor Coat) 工法の断面設計 法一, 電中研研究報告: U93060, 平成6年.

2) 清水隆夫, 池野正明, 氏家久芳, 山内一晃: 波 と水中放流による洗掘対策工放の提案（その 2 )

-SPAC (Spreading Armor Coat) 工法の平面設計 法一, 電中研研究報告: U93061, 平成6年.

3）牛島 省, 田中伸和: 3 次元境界適合座標系を用 いた局所洗掘現象の数值解析, 水工学論文集, 第39巻, pp.683-688, 1995.

4) Ushijima, S.: Arbitrary Lagrangian-Eulerian numerical prediction for local scour caused by turbulent flows, Journal of Computational Physics, 125, pp71-82, 1996.

5) Hirt, C. W., Amsden, A. A. and Cook, J. L.: An arbitrary Lagrangian-Eulerian computing method for all flow speeds, Journal of Computational Physics, 14, pp.227-253, 1974.

6) Thompson, J. F., Warsi, Z. U. A. and Mastin, C. W.: Numerical Grid Generation, Elsevier Science, New York, 1985.

7) Ushijima, S., Moriya, S. and Tanaka, N.: Internal standing waves in a cylindrical vessel and their nearwall features, ASME, J. Heat Transfer, Vol.115, pp.613-620, 1993.

8) Ushijima, S.: Prediction of thermal stratification in a curved duct with 3D body-fitted coordinates", International Journal for Numerical Methods in Fluids, Vol.19, pp.647-665, 1994.

9）小国力編著: 行列計算ソフトウエア, 丸善株式 会社, 平成 5 年.

10) Nils R. B. Olsen and Morten C. Melaaen: Threedimensional calculation of scour around cylinders, ASCE Journal of Hydraulic Engineering, Vol. 119, No. 9, pp.1048-1054, 1993.

11) Nakagawa, H. and Tsujimoto, T.: Sand bed instability due to bed load motion, Proc. ASCE, Journal of the Hydraulics Division, 106, HY 12, pp.2029-2051, 1980.

12) Jonsson, I. G.: Wave boundary layers and friction factors, Proc. 10th Conf. on Coastal Eng., pp.127-148, 1966.

(1997. 9. 30受付) 